\title{
THE FAILURE OF TRANSITIONAL JUSTICE IN AFGHANISTAN: THE POLITICAL DIMENSION
}

\author{
Bilal Badloon \\ Assistant Professor \\ Department of International Relations \\ Law and Political Science Faculty \\ Nangarhar University, Afghanistan \\ E-mail: b.badloon@gmail.com \\ (D) https://orcid.org/0000-0002-8894-8634
}

Received: August 30, 2021

DOI: 10.46281/aijssr.v10i1.1530
Accepted: October 30, $2021 \quad$ Online Published: December 31, 2021

URL: https://doi.org/10.46281/aijssr.v10i1.1530

\begin{abstract}
In every phase of the conflict in Afghanistan, serious War Crimes and crimes against humanity were committed, resulting in mass killings and forced displacement of millions of Afghan civilians and political opponents. Based on relevant literature, this article investigates the political factors responsible for the failure of transitional justice in Afghanistan, particularly internal and external factors. The article also brings to the fore the impact of the dual process of state-building and peace-building on the implementation of transitional justice. In addition, the paper investigates why the 'Peace first and justice later' strategy proved to be unsuccessful in Afghanistan as the Taliban continued their atrocities, fighting Afghan forces and killing innocent people in suicide attacks. The paper finds that the failure of transitional justice in Afghanistan is due to both internal and external factors. Further, the paper finds that Afghanistan has never been a post-conflict state, unlike other countries that have experienced transitional justice processes. Therefore transitional justice measures were never implemented.
\end{abstract}

Keywords: Afghanistan, Transitional Justice, Peace, Conflict.

JEL Classification Codes: F51, F5.

\section{INTRODUCTION}

In the past 30 years, Afghanistan has continuously been involved in a protracted conflict. During the long years of armed conflict, the people of Afghanistan suffered from gross human rights violations. The country has experienced mass executions, disappearances, tortures, ethnic persecution, internal and external migrations to Pakistan, Iran, India and elsewhere. Almost every Afghan has a story of suffering, struggle and loss to tell.

After the fall of the Taliban regime in 2001, many Afghans were hopeful that the violence would end immediately and justice will prevail. However, the intensity of violence has slowed down but did not end totally. In the early stages of nation-building and peace-building, the government of Afghanistan and the international community totally ignored the concept of 
transitional justice. After subsequent internal failed attempts to ensure transitional justice to the victims of the long conflict, the last door towards justice was recently closed when the International Court of Justice (ICC) refused to investigate War Crimes and crimes against humanity in Afghanistan.

\section{RESEARCH METHODOLOGY \& DATA COLLECTION STRATEGY}

This study adopts the post-positivist qualitative methodology and applies empirical and singlecase study methods. The rationale behind the selection of Qualitative Research methodology is that "it has an unrivalled capacity to constitute compelling arguments about how things work in a particular context (Mason 2002). The selection of single-case study will provide "more comprehensive and more detailed contact with concrete instances of the events.... (C)ase studies also provide our best knowledge of how those [structural and institutional] changes come about (Odell 2001)."

This research generally depends on primary and secondary sources. Sources of data include official declarations, speeches of public officials, news reports, relevant books and journal articles.

\section{TRANSITIONAL JUSTICE}

Transitional justice is 'the full range of processes and mechanisms associated with a society's attempts to come to terms with a legacy of large-scale abuses in order to ensure accountability, serve justice and achieve reconciliation" (Rush, Simic, 2014). It includes judicial and nonjudicial mechanisms used to address the legacies of crimes against humanity and war crimes after a conflict end or regime change. Transitional Justice is about conditions in which a nationstate moves from a state of injustice to justice, from authoritarianism to democracy and an oppressive government that respects the rule of law.

'At first, it referred to the judicial process of addressing human rights violations committed by dictatorial or repressive regimes in the course of democratic transition. Later on, the term also came to be used for processing war crimes and massive human rights abuses committed in violent conflicts' (Fischer, 2011). Today it covers the establishment of truth commissions and documentation for recognising the suffering of victims, establishing special tribunals for prosecuting the perpetrators of atrocities, reparations and also social and political initiatives devoted to reconciliation fact-finding, and cultures of remembrance.

\section{THREE PHASES OF THE CONFLICT IN AFGHANISTAN}

Since 1978 Afghanistan has been continuously at war. The period of war up until the end of the Taliban regime is generally divided into three phases. The first phase started with a bloody topdown coup launched by the Marxist-Leninist People's Democratic Party (PDPA) in 1978, followed by the Soviet Union invasion in 1979, which resulted in the repression of Afghan people by two factions of PDPA-Khalq and Parcham ${ }^{1}$ for a decade. Most of the atrocities, including forced disappearances, mass killings and forced displacement of ordinary civilians and political opponents, occurred during this period of the conflict." (Nadery, 2007).

The first phase ended with the withdrawal of the Soviet Union and the fall of the Afghan government under Najibullah. The second phase started with the formation of the Mujahedeen government in 1992. Soon after, the different factions of Mujahedeen became involved in fighting each other. The reason Mujahedeen parties did not come to a consensus was that they

\footnotetext{
${ }^{1}$ Khalq and Parcham: two different factions of the PDPA.
} 
had 'contradictory objectives: Hezb-e Jamiat(predominantly Tajik), Hezb-e-Islami(Pashtun), Hezb-e- Wahdat(Hazara) and Hezb-e- Junbish were fighting to gain local autonomy and control in the future government' (Dorronsoro, 2007, p.28). As a result, Kabul witnessed a civil war between political parties that fought against the Soviets. Chaos erupted once again, and Kabul was bombarded with rockets and RPGs, resulting in gross human rights violations such as killing, raping, and looting innocent people.

The third phase is coincided with the emergence of the Taliban and then controlling major parts of Afghanistan between 1996 and 2001. During this phase along with the lethal violence inflicted on Afghans, the primary victims were women, religious and ethnic minorities. For the first time, the ethnic and religious violence institutionalised to the considerable extent where both the Taliban and the minorities massacred each other in heinous manners.

In every phase of the war, serious war crimes and crimes against humanity, including massacres, disappearances, summary executions, indiscriminate bombings, mass rape and torture had been committed by almost all the armed groups that fought in the country. As a result, 'more than a million Afghans lost their lives, approximately two million were disabled by the conflict, and thousands more were detained and tortured for their political beliefs. And throughout three decades of war, more than seven million were forced to leave the country and take refuge in Pakistan and Iran and elsewhere' (Nadery, 2007).

\section{THE STATE OF TRANSITIONAL JUSTICE IN AFGHANISTAN}

The Bonn Agreement under the United Nations auspices in 2001 did not address transitional justice issues, and no mechanisms were discussed to deal with the past abuses. Rama Mani mentions that 'there were no motives made to address the causes of war and fears of not reaching an agreement resulted in silence' (Mani, 2003). Besides, most of the participants from Afghanistan in the conference were leaders who were part of the conflict and civil war.

The United Nations Assistance Mission in Afghanistan (UNAMA) was established in 2002 to facilitate the implementation of the Bonn agreement. Important issues such as human rights and national reconciliation were on the agenda of UNAMA. However, 'at least in the early stages, UNAMA did not give sufficient priority to the protection and promotion of human rights and the mission was reluctant to take forward the initiative on the investigation of past War Crimes and human rights abuses' (Uesugi, 2009). Barnett Rubin also shares this attitude as he wrote in 2003 that "No major human rights organisation... has called for the establishment of any special tribunal, international or mixed, to try war criminals in Afghanistan." (Rubin, 2003). Cries for transitional justice were not heard and muted in the initial days of post-Taliban Afghanistan.

However, the establishment of the Afghanistan Independent Human Rights Commission (AIHRC) was another significant opportunity to address War Crimes. After discussions on past committed_crimes, the AIHRC authorised the commission to launch a national consultation and propose a national strategy for transitional justice. "Based on a nation-wide consultation among 6,000 participants, the AIHRC published its much-cited report "A Call for Justice" (2005), which established that almost 70\% of Afghans consider themselves direct or indirect victims." (Saeed, \& Parmentier, 2017). The Action Plan identified five key components of justice and reconciliation for Afghanistan, including 'truth-seeking, symbolic measures, accountability mechanisms involving vetting procedures, institutional reform, and reconciliation' (Winterbotham, 2010). The national action remained with its mandate expiring in March 2009. However, the Action Plan was not renewed and extended because of significant opposition from the parliament and government members. 
In 2007 the Wolesi Jirga ${ }^{2}$ followed by the Meshrano Jirga ${ }^{3}$, passed a National Stability and Reconciliation Resolution (The Amnesty Law). Amnesty law was in many ways a death blow to the formal transitional justice process in Afghanistan, ensured blanket amnesty to all the political wings and hostile parties who had been in conflict before the formation of the interim administration, thus turning impunity into law. According to this law, 'all those who committed violence and human rights violations before December 2001 shall enjoy all their legal rights and shall not be prosecuted' (Human Rights Watch, 2012). The amnesty law shattered any hope for transitional justice that many Afghans were yearning to see. With the inability of the Afghan government to ensure transitional Justice to Afghan citizens, the last hope of the people was to an external authoritative organisation to investigate the committed crimes.

The International Criminal Court (ICC) was established in 2002 to investigate crimes against humanity and War Crimes. Afghanistan joined the ICC in 2003, but until now, ICC has not been able to investigate cases of human rights violations from Afghanistan. Although, for the first time in '2017, a request was made by 'Fatou Bensouda to investigate crimes against humanity by the US forces, Afghan National Security Forces, and the Taliban. But the US challenged and threatened that they would revoke and restrict visas of ICC staff responsible for Afghanistan investigation, which eventually led to the rejection of investigation of human rights violations' (Human Rights Watch, 2019).

\section{THE FAILURE OF TRANSITIONAL JUSTICE}

Certain efforts were made to ensure transitional justice to the victims of prolonged conflict after the formation of the new government in 2001, with no result. The failure of transitional was due to the strong opposition of human rights violators, the reluctance of the international community, lack of stability and inability of the Afghan government to ensure justice to the victims of conflict.

Special tribunals were formed for the former Yugoslavia and Rwanda in 1993 and 1994 and the special tribunal to prosecute Saddam Hussain was established in Iraq. But in Afghanistan, no major organisation dealing with human rights issues initiated any process to bring justice and try war criminals. With the only exception of AIHRC recommending to establish a War Crimes Tribunal to execute those accused of war crimes but faced severe criticism from the Afghanistan parliament. Afghanistan became a member of the International Criminal Court (ICC) in 2003, but so far, ICC has not prosecuted a single person from Afghanistan and recently called off the investigation on war crimes committed in Afghanistan after receiving threats of revoking visas from the US.

An important part of vetting "processes for assessing an individual's integrity as a means of determining his or her suitability for public employment", which countries in transition from war to peace, from authoritarian to democratic regimes, often employ in order to mark a new beginning. (Uesugi, 2009). Vetting and transitional justice are directly connected when the records of past committed crimes and human rights abuses are taken seriously in appointing public employees or candidates for public employment. Seeking accountability for past abuses and crimes can removecriminals from their prestigious positions.

Although Afghanistan's constitution prohibits anyone convicted of crimes against

\footnotetext{
${ }^{2}$ Wolesi Jirga: Lower House of Parliament

${ }^{3}$ Meshrano Jirga: Council of Elders
} 
humanity to run for any public office' (Gossman, 2013), until now, no one has ever faced charges for such crimes. Also, the constitution does not provide a mechanism for vetting candidates. In Emergency Loya Jirga (ELJ), held in 2002, impunity was entrenched further. In addition, the vetting criteria of ELJ required candidates to sign a paper swearing they were not involved in killing innocent people or engaged in drug trafficking or terrorism. Despite this, in the event, many known to have violated these conditions were present (Rubin, 2003).

In contradiction to the outspoken wishes of the Afghanistan people for vetting government officials, some of the best-known human rights violators have taken up important official posts. 'One respondent consequently described Mohammad Qasim Fahim, implicated in both war crimes and drug trafficking as a "huge setback to the transitional justice initiative." The return to Kabul of Abdul Rashid Dostum, leader of Junbish-i-Milli, believed to be guilty of many crimes, including the massacre at Dasht-i-Leili in 2001' (Risen, 2009).

The conflict Mapping project was launched in 2005 by the Afghanistan Independent Human Rights Commission(AIHRC), a mammoth report detailing crimes committed by all parties to the conflict- the Soviet forces, PDPA, Mujahideen, and militia. However, the commission was not permitted by the government of Afghanistan to publish the report. In 'December 2011, however, President Karzai took action against the commissioner overseeing the report, Nader Nadery, who had also been an outspoken critic of electoral fraud in Karzai's bid for reelection in 2009. Karzai did not renew Nadery's term at the AIHRC, leaving the report's fate unclear' (Gossman, 2013).

Juan Mendez mentioned that 'truth-telling mechanisms can be important instruments in the search for accountability, but he cautions that certain minimal conditions must be met for these mechanisms to be effective' (Méndez, 2006). In Afghanistan, no such consensus has been reached. The Action Plan on Peace, Justice, and Reconciliation outlined the truth-seeking and documentation mechanism. However, the plan was endorsed in 2006 but with no practical measures. In reaction to this initiative, parliament passed Amnesty Law and gave impunity to human rights violators.

\section{REASONS FOR THE FAILURE OF TRANSITIONAL JUSTICE}

Immediately after the defeat of the Taliban, little attention was directed to transitional justice. Any attempt to pursue transitional justice and to seek accountability for committed crimes faced various challenges. Firstly, justice for past abuses was of secondary importance because of other serious problems such as insecurity, instability, and poverty in Afghanistan. Secondly, ensuring justice to the victims was considered to be risking the achievements of the newly-formed Afghan government. Yuji Uesugi as a senior official of the UN, said in 2002 that "transitional justice only applies to the post-conflict situation and Afghanistan is not in a post-conflict phase" (Uesugi, 2009). After the defeat of the Taliban regime, Afghanistan remained unstable, and the waves of the violence continued while the United States and its coalition forces went on with the campaign for the 'War on Terror".

The crucial role of warlords in the government and power-sharing processes became a significant obstacle to transitional justice because any attempt to address the past War Crimes and violence would naturally point fingers at those in power. During the meeting for drafting the peace agreement in 2001, the clause that "there would be no amnesty for crimes against humanity and war crimes" met strong opposition from the Northern Alliance (NA) delegation for the reason that it would "defame the struggle of the mujahedeen" (Rubin, 2003). As long as warlords were able to secure important positions in the government, it was neither realistic nor preferable 
to seek accountability for serious human rights abuses.

After the arrival of the US-led NATO forces in 2001, their main goal was to defeat AlQaeda and the Taliban. In order to defeat them, the cooperation of influential warlords who had fought against the Taliban was needed. Most of these warlords were allegedly responsible for the country's long war as well as for committing serious crimes not only in the past but also during the war against the Taliban. The cooperation of the warlords was necessary for the peace and stability of the country. Some of the human rights violators were appointed to the high ranks of the government. "Abdul Rashid Dostum who is reported to have "killed hundreds of Taliban prisoners while transporting them in sealed containers from Kunduz towards Mazar-e Sharif" (Human Rights Watch, 2003, p. 198), returned from exile and later on became the vice president in 2014 presidential election.

Another important hurdle to the application of transitional justice was the lack of stability and security. Ensuring security remained the priority after the defeat of the Taliban. The prioritisation of national security led to lenient attitudes towards human rights violators. In an interview, former president Hamid Karzai said, "We must first have peace, stabilise peace, make it certain, make it stand on its own feet, and then go for justice. But if we can have justice while we are seeking peace, we'll go for that too. He concluded: So... justice becomes a luxury for now. We must not lose peace for that" (Kolhatkar, Ingalls, 2011). It meant that warlords who have committed war crimes would not be held responsible. This was also reiterated by the Lakhdar Ibrahimi, head of the UNAMA by saying that, "our responsibility to the living has to take precedence over justice to the dead" (Uesugi, 2009, p.106). Without peace and stability guaranteeing justice for past crimes is regarded as dangerous and naive.

In addition, immediately after the toppling of the Taliban regime, major countries, particularly the United States and the United Nations, paid only limited attention to the long-term aspect of peace-building in Afghanistan. The international community acted differently in Afghanistan compared to other post-conflict countries on the issue of transitional justice. For instance, the special Tribunal in Iraq prosecuted Saddam Hussain for war crimes and crimes against humanity. However, instead of prosecuting warlords and human rights violators in Afghanistan, they became part of the government.

The main objective of eliminating the Taliban and Al-Qaeda did not allow the Afghan government and international community to seriously consider the long-term aspect of justice and reconciliation in Afghanistan. The US forces contracted many anti-Taliban Afghan warlords because they were needed against the Taliban and Al-Qaida. Barnett Rubin argues that along with the fighting, the United States armed, financed, and supported them; even after defeating the Taliban, this support continued in order to proceed with the war on terror (Rubin, 2003).

Failure of the Afghan government to take hold of perpetrators of severe crimes resulted in retributive violence and paved the way for more grave crimes. Although not a single person has been brought to justice in post-Taliban Afghanistan, in contrast, amnesty became institutionalised through the Amnesty Law of 2007.

\section{THE APPROACH OF "PEACE VS JUSTICE" IN AFGHANISTAN}

The concept of 'peace vs justice' was first introduced by the former General Secretary of United Nations Kofi Annan in a report on transitional justice and the rule of law in post-conflict countries. He stressed that justice and peace are not contradictory forces. Rather, if properly pursued, they promote and sustain one another. The question, then, can never be whether to pursue justice and accountability (Secretary-General, 2004). Annan's ideas that peace and 
justice are complementary have not taken roots in the context of Afghanistan. Rather, the Afghan government and the international community sacrificed justice for achieving peace. The justification for sacrificing justice is that ensuring transitional justice could disrupt the peace process.

As expressed by Nobel peace laureate Rigoberta Menchú, 'Peace without justice is only a symbolic peace' (Gunson, 1996). While the relationship between peace and justice seems almost undeniable, it is no simple matter of remarrying the two once violent conflict has ripped them asunder. Afghanistan has witnessed the 'adoption of six peace agreements in the last 40 years, each accompanied by blanket amnesties for perpetrators of the most heinous crimes in the name of peace." (Dwivedi, 2017). Today Afghanistan has neither peace nor justice for the victims of past atrocities and thousands still suffering from the waves of violence in Afghanistan. The transitional justice has been hampered by the concept of peace in the context of Afghanistan, especially with the gradual increase in the insurgency. Without addressing past committed crimes, bringing peace is proven to be wrong in the context of Afghanistan.

The approach of "peace first and justice later" remained the core policy of Afghanistan till the present time. It is quite visible in Ashraf Ghani's move towards Hezb-e-Islami of Gulbuddin Hekmatyar and the Taliban. In a peace agreement between 'National Unity Government and Hezb-e-Islami in 2016, its criminal records were cleared, and its prisoners were released from jails' (Tolo News, 2018). The reason behind signing the peace treaty with the Hekmatyar without holding him responsible for crimes he committed was to persuade the Taliban. 'Peace first and justice later' proved to be unsuccessful in Afghanistan, when the Taliban continued their atrocities, fighting Afghan forces and killing innocent people in suicide attacks.

\section{CONCLUSION}

In the past 30 years, Afghanistan has continuously been involved in protracted conflicts. During the long years of armed conflict, the people of Afghanistan suffered from gross human rights violations. The country has experienced mass executions, disappearances, tortures, ethnic persecution, internal and external migrations to Pakistan, Iran, India and elsewhere. The failure of transitional was due to the strong opposition of human rights violators, the reluctance of the international community, lack of stability and inability of the Afghan government to ensure justice to the victims of conflict. However, the failure cannot be attributed to the Afghan government alone, but the international community also acted indifferently. The international community paid little attention to the long-term aspect of peace-building in Afghanistan and acted differently compared to other post-conflict countries on the issue of transitional justice.

The decades-long strategy of "peace first, justice later" proved that peace would not be achieved until justice is not sought simultaneously with peace. Sustainable peace will require accountability and punishing those who are guilty of severe crimes. However, in the context of Afghanistan, the human rights violators became the government's decision-makers after 2001. Transitional Justice is not merely a matter of past and present, but in fact, ignoring justice pave the way for future crimes.

\section{REFERENCES}

Dorronsoro, G. (2007). Kabul at war (1992-1996): State, ethnicity and social classes. South Asia Multidisciplinary Academic Journal.

Dwivedi, N. (2017). Afghanistan: Choosing Peace Over Justice. The Diplomat. Retrieved April 
22, 2021, from https://thediplomat.com/2017/07/afghanistan-choosing-peace-overjustice/.

Fischer, M. (2011). Transitional justice and reconciliation: Theory and practice.

Gossman, P. (2013). Documentation and Transitional Justice in Afghanistan. Universitäts-und Landesbibliothek Sachsen-Anhalt.

Gunson, P. (1996). Guatemala's "Peace without Justice"', Guardian, 28 December. Retrieved April 22, 2021, from https://www.hrw.org/legacy/wr2k3/pdf/afghanistan.pdf.

Saeed, H., \& Parmentier, S. (2017). When rabbits are in charge of carrots: Land grabbing, transitional justice and economic-state crime in Afghanistan. State Crime Journal, 6(1), 13-36.

Human Rights Watch. (2003). Human Rights Watch Report on Afghanistan. Retrieved April 22, 2021, from https://www.hrw.org/legacy/wr2k3/asia1.html

Human Rights Watch. (2012). Afghanistan: No Amnesty for Taliban Crimes. Retrieved April 22, 2021, from https://www.hrw.org/news/2012/11/25/afghanistan-no-amnesty-talibancrimes. Accessed: (22/04 2021).

Human Rights Watch. (2019). 'ICC: Judges Reject Afghanistan Investigation', HRM. Retrieved April 22, 2021, from https://www.hrw.org/news/2019/04/12/icc-judges-rejectafghanistan-investigation. Accessed: (22/04 2021).

Kolhatkar, S., \& Ingalls, J. (2011). Bleeding Afghanistan: Washington, warlords, and the propaganda ofsilence. Seven Stories Press.

Mani, R. (2003). Ending impunity and building justice in Afghanistan. Afghanistan Research and Evaluation Unit.

Mason, J. (2002). Qualitative researching. $2^{\text {nd }}$ Edition. Sage.

Méndez, J.E. (2006). The human right to truth: Lessons learned from Latin American Experiences with truth telling. Telling the truths: truth telling and peace building in postconflict societies, pp.115-50.

Nadery, A.N. (2007). Peace or Justice? Transitional Justice in Afghanistan. The International Journal of Transitional Justice, 1(1), 173-179.

Odell, J.S., (2001). Case study methods in international political economy. International Studies Perspectives, 2(2), pp.161-176.

Risen, J., (2009). US Inaction Seen After Taliban POW's Died. New York Times, 10, p.2009. 
Rubin, B.R., (2003). Transitional Justice and human rights in Afghanistan. International Affairs, 79(3),pp.567-581.

Rush, P.D., \& Simic, O. (2014). The Arts of Transitional Justice. New York:

Secretary-General. (2004). Rule of law and transitional Justice in conflict and post-conflict societies. Report of the Secretary-General. UN Doc. S/2004/616.

Tolo News. (2016). Details Of Peace Agreement Mapped Out. Retrieved April 22, 2021, from https://www.tolonews.com/afghanistan/details-peace-agreement-mapped-out. Accessed: (22/04 202`).

Uesugi, Y. ed., (2009). Toward Bringing Stability in Afghanistan: A Review of the Peacebuilding Strategy. Institute for Peace Science, Hiroshima University.

Watch, HR, (2005). Blood Stained Hands, Past Atrocities in Kabul and Afghanistan's Legacy of Impunity.

Winterbotham, E. (2010). The State of Transitional Justice in Afghanistan. Universitäts-und Landesbibliothek Sachsen-Anhalt.

Conceptualization: Bilal Badloon

\section{AUTHOR CONTRIBUTIONS}

Data Curation: Bilal Badloon

Formal Analysis: Bilal Badloon

Funding Acquisition: Bilal Badloon

Project Administration: Bilal Badloon

Software: N/A

Validation: Bilal Badloon

Writing - Original Draft: Bilal Badloon

Writing - Review \& Editing: Bilal Badloon

\section{CONFLICT OF INTEREST STATEMENT}

The author declare that he has no competing interests.

\section{Copyrights}

Copyright for this article is retained by the author(s), with first publication rights granted to the journal. This is an open-access article distributed under the terms and conditions of the Creative Commons Attribution license (https://creativecommons.org/licenses/by/4.0) 